\title{
Retinochoroiditis in acute Epstein-Barr virus infection
}

\author{
S P KELly,' A R ROSENTHAL, ${ }^{1} \mathrm{~K}$ G NICHOLSON, ${ }^{2}$ AND C G WOODWARD \\ From the 'Department of Ophthalmology, Leicester Royal Infirmary, ${ }^{2}$ Department of Infectious Diseases, \\ Groby Road Hospital, Leicester, and ${ }^{3}$ Public Health Laboratory, Leeds
}

SUMMARY The case is reported of a 17-year-old male with secondary glaucoma and retinochoroiditis complicating acute clinical infectious mononucleosis. The diagnosis was confirmed by EpsteinBarr virus specific serology. Toxoplasmic infection was initially suspected. The differential diagnosis and relevant literature are discussed.

A recent awareness of the role of the Epstein-Barr virus (EBV) in ophthalmic diseases exists. ${ }^{1-5}$ We describe a patient which further substantiates this association.

\section{Case report}

A 17-year-old male presented with pain and blurred vision in the left eye. Three weeks previously he had had an influenza-like illness with sore throat and cervical lymphadenopathy. Oral erythromycin had been prescribed. Ten days later he developed a maculopapular rash on the trunk.

The visual acuity was $6 / 6$ Snellen right and finger counting at $1 / 3$ meter left. The right eye was white, with no evidence of anterior chamber activity. There were $1+$ cells in the right vitreous cavity and a discrete area of active retinitis of less than 1 disc diameter centred on a retinal vessel superior to the macula. In the left eye there were $3+$ external injection, corneal stromal oedema, multiple large keratic precipitates, a relative afferent pupil defect, $3+$ anterior chamber cells, and intraocular pressure of $40 \mathrm{~mm} \mathrm{Hg}$ by Goldman applanation tonometry. Koeppe iris nodules were present. There were $3+$ cells in the vitreous cavity and a large area of active, white, fluffy retinitis with a fresh retinal haemorrhage in its centre at the posterior pole, with overlying vitreous haze (Fig. 1). Retinal vascular sheathing was present, with staining of vessel walls on fluorescein angiography. The left optic disc was oedematous. Systemic examination revealed a fading maculopapular rash on the trunk, cervical lymphadenopathy, and mild splenomegaly. Serum electrolytes and liver function tests were normal. There were $2 \%$

Correspondence to Simon P Kelly, FRCSEd, Manchester Royal Eye Hospital, Oxford Road, Manchester M13 9WH. atypical lymphocytes. Serological tests for syphilis and human immunodeficiency virus were negative. Serology (Table 1) confirmed acute EBV infection and prior toxoplasma infection. EBV serology was performed by conventional immunofluorescent staining, ${ }^{6}$ employing screening dilution of $1 / 8$ for viral capsid antigen (VCA) and 1/2 for Epstein-Barr nuclear antigen (EBNA), and by peroxidase staining? following the maker's protocol.

The patient was prescribed clindamycin $450 \mathrm{mg}$, prednisolone $60 \mathrm{mg}$, and acetazolomide $1 \mathrm{~g}$ daily by mouth initially. The prednisolone was reduced over a 10-day period. Dexamethasone $0 \cdot 1 \%$ and mydriatic

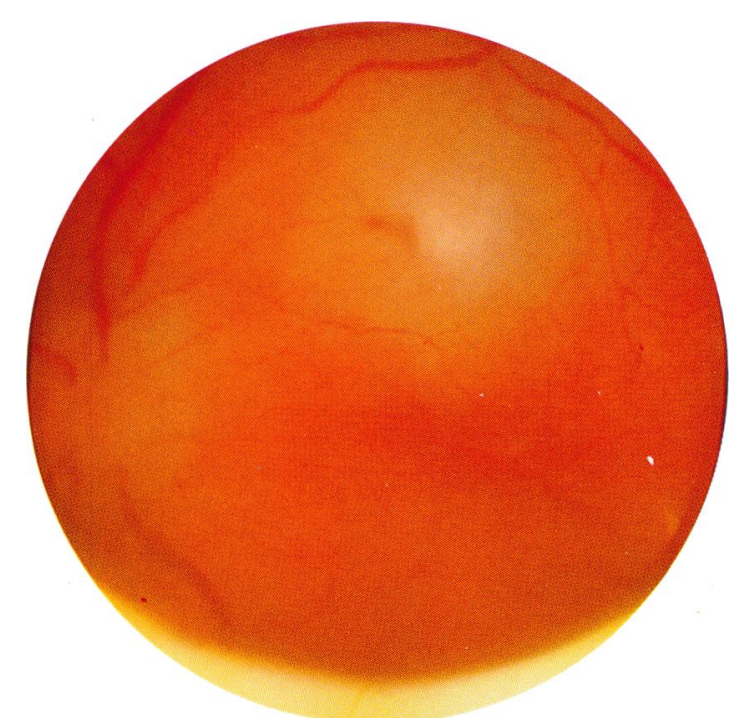

Fig. 1 Left eye. Active retinochoroiditis with optic disc oedema seen through the vitreous haze. 
Table 1 Results of antibody studies

\begin{tabular}{|c|c|c|c|}
\hline Serum antibody & Initial & $\begin{array}{l}\text { One } \\
\text { month }\end{array}$ & $\begin{array}{l}\text { Eight } \\
\text { months }\end{array}$ \\
\hline Epstein-Barr viral capsid IgG & $1 / 16$ & $1 / 16$ & $1 / 32$ \\
\hline $\begin{array}{l}\text { Epstein-Barr viral capsid IgM } \\
\text { by fluorescent staining }\end{array}$ & Positive & Equivocal & Negative \\
\hline $\begin{array}{l}\text { Epstein-Barr viral capsid IgM } \\
\text { by peroxidase staining* }\end{array}$ & Positive & Negative & Negative \\
\hline Epstein-Barr nuclear antigen & Negative & NT & Positive \\
\hline Rheumatoid factor & Negative & Negative & Negative \\
\hline Paul-Bunnel test & $\geqslant 1 / 14336$ & NT & NT \\
\hline $\begin{array}{l}\text { Paul-Bunnel after absorption } \\
\text { with guineapig antigen }\end{array}$ & $\geqslant 1 / 14336$ & NT & NT \\
\hline Ox cell antigen & $\leqslant 1 / 7$ & NT & NT \\
\hline Cytomegalovirus & $\leqslant 1 / 16$ & $\leqslant 1 / 16$ & NT \\
\hline Herpes simplex & $\leqslant 1 / 16$ & $\leqslant 1 / 16$ & NT \\
\hline Herpes varicella zoster & $\leqslant 1 / 16$ & $\leqslant 1 / 16$ & NT \\
\hline Toxoplasma dye test & $1 / 256$ & $1 / 256$ & $1 / 512$ \\
\hline Toxoplasma IgM ELISA & Negative & Negative & Negative \\
\hline
\end{tabular}

NT= not tested. *Ipazyme True-IgM, Biological

Industries Ltd, Cumbernauld, UK.

eye drops were instilled. The intraocular inflammatory signs abated rapidly and vision had recovered to $6 / 36$ Snellen by day 7 . A white, atrophic macular scar finally occurred, with surrounding pigmentation.

\section{Discussion}

EBV infection occurs in most young adults in developed countries, producing an infectious mononucleosis (IM) syndrome of fever, tonsillopharyngitis, and lymphadenopathy. Follicular conjunctivitis is the most common ocular manifestation of acute EBV infection. ${ }^{\gamma}$ Keratitis and optic neuritis are also recognised. ${ }^{249}$ Aseptic meningitis, encephalitis, transverse myelitis, Guillain-Barré syndrome, and cranial nerve palsies are occasional neurological complications of acute EBV infection. ${ }^{10}$

The differential diagnosis of chorioretinitis of infectious aetiology includes cytomegalovirus (CMV), Toxoplasma gondii, herpes simplex and zoster virusus, and syphilitic infections. "Despite the systemic clinical and haematological similarities of acute EBV infection and acquired CMV or Toxoplasma gondii infections, chorioretinitis is not an established manifestation of clinical EBV infections. Raymond et al recently described punctate outer retinitis in a child during a clinical episode of active EBV infection. ${ }^{5}$ There was no anterior uveal activity in that case. Toxoplasmic retinochoroiditis was initially suspected, as in our patient. Acquired systemic toxoplasma infection with associated retinitis is unusual and has been serologically excluded in our patient. ${ }^{1213} \mathrm{~A}$ reactivation of a previous toxoplasmic focus seems unlikely, as there were no old chorioretinal scars. Tiedeman described multifocal choroididitis with panuveitis in otherwise healthy patients who had serological evidence of recent or continuing chronic EBV infection, without acute IM-like illnesses. ${ }^{3}$ Bonamour and Pommier described acute chorioretinitis with a positive PaulBunnel result but did not include fundal photographs. ${ }^{14}$ Isolated case reports of retinal changes in association with IM exist ${ }^{15}{ }^{16}$ but do not resemble the acute chorioretinitis of either Bonamour and Pommier's patient or ours.

Ophthalmologists need to consider EBV infection among the differential diagnoses of acute retinochoroiditis and request appropriate serological tests. Ocular manifestations of EBV infection may be more widespread than suspected.

We are grateful to Dr A G E Flower, Virology Department, Leicester Royal Infirmary, for advice on the serology levels.

1 Aaberg TM, O’Brien WJ. Expanding ophthalmologic recognition of Epstein-Barr virus infections. Am J Ophthalmol 1987; 104: 420-3.

2 Matoba AY, Wilhemus KR, Jones DB. Epstein-Barr viral stromal keratitis. Ophthalmology 1986; 93: 746-51.

3 Tiedeman JS. Epstein-Barr viral antibodies in multifocal choroiditis and panuveitis. Am J Ophthalmol 1987; 103: 659-63.

4 Wong KW, D’Amico DJ, Hedges TR, Soong HK, Schooley RT, Kenyon KR. Ocular involvement associated with chronic Epstein-Barr virus disease. Arch Ophthalmol 1987; 105: 788-92.

5 Raymond LA, Wilson CA, Linnemann CC, Ward MA, Bernstein DI, Love DC. Punctate outer retinitis in acute Epstein-Barr virus infection. Am J Ophthalmol 1987; 104: 424-5.

6 Henle G, Henle W. Diagnosis of Epstein-Barr virus infections. In: Nahmias AJ, Dowdle WR. Schinazi RF, eds. The human herpes viruses: an interdisciplinary perspective. New York: Elsevier, 1981: 374-8.

7 Woodward CG. A comparison of assay methods for the detection of antibodies to Epstein-Barr virus. Serodiagnosis and Immunotherapy in Infectious Diseases 1988; 2: 461-5.

8 Tanner OR. Ocular manifestations of infectious mononucleosis. Arch Ophthalmol 1952: 51: 229-41.

9 Jones J, Gardner W, Newman T. Severe optic neuritis in infectious mononucleosis. Ann Emerg Med 1988; 17: 361-4.

10 Ho DD, Hirsch MS. Acute viral encephalitis. Med Clin North Am 1985; 69: 415-29.

11 Smith RE, Nozik RA. Uveitis: a clinical approach to diagnosis and management. Baltimore: Williams and Wilkins, 1983: 87-90).

12 Saari M, Vuorre I, Neiminen H, Räisänen S. Acquired toxoplasmic chorioretinitis. Arch Ophthalmol 1976; 94: 1485-9.

13 Akstien RBV, Wilson LA. Teutsch SM. Acquired toxoplasmosis Ophthalmology 1982: 89: 1299-1306.

14 Bonamour G. Pommier ML. Manifestations chorio-rétiniennes dans la mononucléose infectieuse. Bull Soc Ophtalmol Fr 1968: 68: $52-4$.

15 Richard J. Infectious mononucleosis, retinopathy, fixed pupils and seizure complications. NY State J Med 1975; 75: 1547-9.

16 Karpe G, Wising P. Retinal changes with acute reduction of vision as initial symptom of infectious mononucleosis. Acta Ophthalmol (Kbh) 1948; 26: 19-24.

Accepted for publication 7 June 1989. 